\title{
Percutaneous Trocar Drainage of a Hepatic Abscess in a Sickle Cell Disease Patient - A Case Report
}

Oludapo O Afuwape and ljeoma N Chibuzo

Department of Surgery, Division of Gastrointestinal Surgery, University College Hospital Ibadan, Nigeria

*Corresponding author: ljeoma N Chibuzo, Department of Surgery, University College Hospital, P.M.B, 5116, Ibadan, Nigeria, E-mail: ijeomanc2002@yahoo.com

Rec date: Nov 29, 2014 Acc date: July 16, 2015 Pub date: July 22, 2015

Copyright: (C) 2015 Afuwape OO, et al. This is an open-access article distributed under the terms of the Creative Commons Attribution License, which permits unrestricted use, distribution, and reproduction in any medium, provided the original author and source are credited.

\begin{abstract}
Introduction: Hepatic abscess as a manifestation of sickle cell disease is rare. To our knowledge there is no report of a large hepatic abscess in these patients, thus documentation of open abd percutaneous drainage techniques alone exist. This is the first report of the use of laparoscopic trocar in the drainage of a massive hepatic abscess in a sickle cell disease patient.

Case presentation: A 25 year old Nigerian Yoruba male with sickle cell disease presented with upper abdominal pain, fever, massive hepatomegaly, neutrophilic leucocytosis and mildly deranged liver enzymes. Ultrasonographic findings were a large thin walled right hepatic lobar abscess, with an estimated volume of 1419 ml. It was nonresponsive to antibiotic therapy. It was evacuated under general anaesthesia via trocar drainage. A size 14Fr nasogastric tube was introduced through the trocar into the abscess cavity as a drain, with good recovery postoperatively.
\end{abstract}

Discussion: Trocar drainage was chosen because of the abscess characteristics, the massive size of the liver which made access with pneumoperitoneum difficult, and the minimally invasive nature of the therapy.

Conclusion: Percutaneous laparoscopic trocar drainage is effective in drainage of liver abscesses. The additional benefits of this minimally invasive treatment in a sickle cell disease patient are reduced trauma, pain and morbidity. This report would benefit gastroenterologists and haematologists for purposes of referral options, and offer surgeons another option of therapy.

Keywords: Hepatic abscess; Trocar drainage; Sickle cell disease

\section{Abbreviations:}

SCD: Sickle Cell Disease; INR: International Normalised Ratio; Fr: French Guage

\section{Introduction}

Hepatic abscesses are space-occupying lesions of infectious origin, which could be pyogenic, amoebic or less frequently, fungal [1]. Hepatic abscesses are uncommon in the general population $(0.029$ to $1.47 \%)$ [2], and are even rarer in those with sickle cell disease [3]. In these patients, reports more commonly follow percutaneous liver biopsies for other pathologies; however, the majority (up to 20\%) are cryptogenic [2].

Patients with sickle cell disease are high risk surgical patients. The use of less invasive surgical modalities in sickle cell patients improves outcome. We report a case of laparoscopic trocar drainage of a hepatic abscess in a sickle cell disease patient.

\section{Case Presentation}

A 25 year old Nigerian Yoruba male, who was diagnosed to have sickle cell disease in childhood, presented with a six week history of high grade intermittent fever and a five week history of progressive right upper quadrant abdominal pain and swelling. The pain was referred to the right shoulder. There was no history of progression of the pre-existing jaundice. He had no pruritus. There was no history of preceding abdominal trauma, hepatobiliary instrumentation, dysentery, respiratory tract infection or recent blood transfusion. He had received multiple courses of oral antibiotics.

On examination, he was acutely ill-looking, pale, febrile $\left(38.6^{\circ} \mathrm{C}\right)$ and had a tinge of jaundice. He was tachycardic, with a pulse of 112 / minute. There was reduced air entry in the right lower lung zone of the chest. The abdomen was asymmetrically distended. He had smooth hepatomegaly of grade II tenderness, $16 \mathrm{~cm}$ below the right costal margin in the mid-clavicular line. The liver span was $20 \mathrm{~cm}$. The admitting diagnosis was a hepatic abscess, with hepatitis and lobar pneumonia as differentials.

Complete blood count revealed a haematocrit of $18 \%$, elevated white blood cell count of $12,550 / \mathrm{mm}^{3}$ with predominant neutrophilia (70.2\%), 23.1\% lymphocytes, $6.5 \%$ monocytes and $0.1 \%$ eosinophils and basophils. The clotting profile was deranged with an international normalised ratio (INR) of 1. 56. Liver function test revealed elevated total serum bilirubin of $2.8 \mathrm{mg} / \mathrm{dl}$, conjugated bilirubin of $2.3 \mathrm{mg} / \mathrm{dl}$, elevated liver enzymes (alkaline phosphatase of $226 \mathrm{iu} / \mathrm{l}$, aspartate amino transferase of $112 \mathrm{iu} / \mathrm{l}$, alanine transaminase of $44 \mathrm{iu} / \mathrm{l})$, hypoalbuminaemia of $2.4 \mathrm{~g} / \mathrm{dl}$ with total protein of $9.4 \mathrm{~g} / \mathrm{dl}$. His serum was non-reactive for Hepatitis $C$ virus, Hepatitis B surface antigen and Human Immunodeficiency Virus. 
The chest X-ray showed elevation of the right hemi-diaphragm. There was no consolidation or effusion. The abdominopelvic ultrasound scan showed hepatomegaly of $22.3 \mathrm{~cm}$ and a huge thinwalled hypoechoic collection in the right lobe of the liver, with an approximate volume of $1419 \mathrm{ml}$.

He was transfused with fresh frozen plasma. The INR normalised to 1.04. Parenteral broad spectrum antibiotics were administered.

He had trocar drainage of the abscess under general anaesthesia. The abscess was localised by aspiration using a $21 \mathrm{G}$ needle. A $1 \mathrm{~cm}$ incision was made at that point and a $5 \mathrm{~mm}$ laparoscopic trocar advanced into the abscess cavity. $3000 \mathrm{ml}$ of pus was drained. An atraumatic grasper was used to break up loculi. A $14 \mathrm{Fr}$ nasogastric tube was inserted as a drain via the trocar, which was then removed. The drain was anchored in place. The procedure lasted thirty minutes.

The post-operative ultrasound scan done revealed an $8 \mathrm{~cm}$ residual collection in the abscess cavity in the right lobe, with a volume of 460 $\mathrm{ml}$. The drain was adjusted with subsequent drainage of a further 1830 $\mathrm{ml}$ on the ward. Repeat ultrasound scan revealed no abscess.

The microbiology, culture and sensitivity of the aspirate yielded pus cells but no growth. This was attributed to the prolonged prior use of antibiotics.

The patient was discharged on the $14^{\text {th }}$ post-operative day without further event.

\section{Discussion}

Pyogenic liver abscesses constitute an uncommon, but lifethreatening pathology, with a mortality of $11-50 \%$ [1,2,4], and $95-100 \%$, if untreated [5-8]. With improvements in treatment, morbidity has reduced 9. It is more common in the developing world due to poor hygiene, ingestion of contaminated food and water, chronic malnutrition and co-morbidities like sickle cell disease, acquired immunodeficiency, and tuberculosis. The mortality increases with attendant co-morbidities, among other independent prognostic factors [6].

Pathologies of the biliary tract are responsible for about $40 \%$ of cases. Pylephlebitis from abdominal pathologies, recent surgeries or hepatic procedures, direct inoculation, contiguous spread have also been implicated. Twenty percent are of cryptogenic origin $[2,4]$. The right hepatic lobe is affected more commonly $(2-4: 1)[2,6]$. Our patient had a right hepatic abscess.

Various modes of presentation exist. The classic triad of upper abdominal pain, fever and hepatomegaly seen in our patient is uncommon [5]. The degree of tenderness was in keeping with that documented by Lamont and Pooler as most common (45.2\% of patients with hepatic abscesses have Grade II tenderness) [7]. Cough, hiccups, anorexia, vomiting and/or weight loss are also symptoms of hepatic abscess.

A hepatic abscess is a rare gastrointestinal manifestation of sickle cell disease [2]. The incidence of hepatic abscesses among sickle cell disease patients is $0.02 \%[9,10]$. The first report was in $1966[11,12]$. The pathophysiology may be attributed to secondary infection of a liver infarct. Ascending cholangitis in those with biliary pathologies like stones, or hepatobiliary procedures may also be implicated. Rarely, iron overload and desferrioxamine therapy in these patients increase risk of pyogenic abscess due to Yersinia enterocolitica [13].
Hepatic abscesses may be treated with antibiotics alone, or via aspiration, percutaneous catheter, trocar or open drainage. Indications for open drainage include multiloculated abscesses, multiple abscesses, abscesses greater than $5 \mathrm{~cm}$, viscid pus, failed percutaneous drainage, ruptured abscess, peritonitis and prior diagnosis of intra-abdominal pathology [5]. The clinical fitness of the patient also determines the treatment modality chosen. Minimally invasive surgery in sickle cell disease patients reduces pain, vaso-occlusive crises, hospital stay and improves mortality [8]. Percutaneous drainage and catheter placement is advised in cases where the primary source is still being sought (as a staged procedure), or in septic patients unable to withstand open surgical procedures $[4,6,12]$. In literature, Kayaalp et al. alone reported the use of a percutaneous laparoscopic trocar for drainage of a hepatic abscess 9 which was less than $2 \mathrm{~L}$.

Although the initial report was under local anaesthesia, our choice of general anaesthesia was due to the need to limit the metabolic response to trauma as a key to improving the outcome in this patient with sickle cell disease; and secondly to permit rapid conversion to open drainage if complications arose. Veress needle-assisted laparoscopic drainage under general anaesthesia has been reported in our environment [14] however three laparoscopic ports were created consequently increasing the postoperative analgesic requirements. In this patient with sickle cell disease, a singular demerit of trocar drainage was the blind placement in the abscess cavity. There was no effluent from the drain initial post-operative period, necessitating a 10 centimetre withdrawal of the catheter to achieve continual drainage. The patient did not require a repeat surgical procedure, and was discharged home eight days later without further event.

Indicators of a poor prognosis in pyogenic abscesses have been described since 1938 by Oschner et al. and Chou [3]. These include multiplicity of abscesses, underlying malignancy, severity of underlying medical conditions, presence of complications, and delay in diagnosis. Indicators of a poor prognosis in amoebic abscess include a bilirubin level of greater than $3.5 \mathrm{mg} / \mathrm{dL}$, encephalopathy, hypoalbuminemia (i.e., serum albumin level of $<2 \mathrm{~g} / \mathrm{dL}$ ), and multiple abscesses; all are independent factors that predict poor outcome [15]. Other than the co-morbid condition of sickle cell disease, our patient lacked these predictors.

\section{Conclusion}

We recommend percutaneous trocar drainage for large hepatic abscesses, even more so, in those with sickle cell disease. To our knowledge, this is the only report of percutaneous laparoscopic trocar drainage of a hepatic abscess under general anaesthesia, and in a sickle cell disease patient.

\section{Consent}

A written informed consent was obtained from the patient for publication of this case report with accompanying photographs and investigation results. A copy of the written consent is available on request for review by the Editor-in-Chief of this journal.

\section{Authors Contributions}

OOA conceived and effected the option of laparoscopic trocar usage in this patient, the choice of anaesthesia and was central to the patient's management. INC participated in the patient's management 
Citation: Afuwape OO, Chibuzo IN (2015) Percutaneous Trocar Drainage of a Hepatic Abscess in a Sickle Cell Disease Patient - A Case Report. Gen Med (Los Angel) 3: 1000195. doi:10.4172/2327-5146.1000195

Page 3 of 3

and contributed greatly to writing up the manuscript. Both authors read and approved the final manuscript.

\section{Authors Information}

OOA is a Consultant General Surgeon, with the Division of Gastrointestinal surgery. He has published various articles on laparoscopic adaptations for and experience in the developing world as well as a laparoscopic training model for trainees.

INC is a third year resident doctor with the department of surgery.

\section{Acknowledgements}

The pecuniary burdens incurred were personally financed.

\section{References}

1. Dutta A, Bandyopadhyay S (2012) Management of liver abscess. Medicine update 22: 469-475.

2. Sayek I, Onat D (2001) Pyogenic and amoebic liver abscess. In: Surgical treatment: Evidence-based and problem-oriented.

3. Lama M (1993) Hepatic abscess in sickle cell anaemia: a rare manifestation. Arch Dis Child 69: 242-243.

4. Rahimian J, Wilson T, Oram V, Holzman RS (2004) Pyogenic liver abscess: recent trends in etiology and mortality. Clin Infect Dis 39: 1654-1659.
5. Nasir AA, Adeniran JO, Abdur-Rahman LO, Abdulkadir AY, Inikori AK, et al. (2009) Pyogenic liver abscess in children: is ruptured appendix still relevant as cause? Case report. Niger Postgrad Med J 16: 176-178.

6. Chen SC, Tsai SJ, Chen CH, Huang CC, Lin DB, et al. (2008) Predictors of mortality in patients with pyogenic liver abscess. Neth J Med 66: 196-203.

7. Kapoor OP (2012) Amoebic liver abscess. Bombay Hosp J 54: 2.

8. Meshikhes AW, al-Faraj AA (1998) Sickle cell disease and the general surgeon. J R Coll Surg Edinb 43: 73-79.

9. Kayaalp C, Yol S, Nessar G (2003) Drainage of liver abscess via laparoscopic trocar with local anesthesia. Surg Laparosc Endosc Percutan Tech 13: 121-124.

10. Mohanty J, Narayan J, Bhagat S (2004) Sonological evaluation of abdominal organs in sickle cell crisis in Western Orissa. Indian J Radiol Imaging 14: 247-251.

11. Shulman ST, Beem MO (1971) An unique presentation of sickle cell disease: pyogenic hepatic abscess. Pediatrics 47: 1019-1022.

12. Kao L (2014) Intra-abdominal abscess.

13. Ebert EC, Nagar M, Hagspiel KD (2010) Gastrointestinal and hepatic complications of sickle cell disease. Clin Gastroenterol Hepatol 8: 483-489.

14. Ekwunife CN, Amadi EC, Amaechi FN, Ukaha IC (2012) Laparoscopyguided Liver Abscess Drainage: An Additional Use of Veress Needle. J Surg Tech Case Rep 4: 36-38.

15. http:/misc.medscape.com/pi/iphone/medscapeapp/html/A188802business.html 